\title{
Party Autonomy in the Procedure of Appointing Arbitrators
}

\author{
Michal Malacka \\ Faculty of Law, Palacky University Olomouc, Czech Republic \\ michal.malacka@upol.cz
}

MALACKA, Michal. Party Autonomy in the Procedure of Appointing Arbitrators. International and Comparative Law Review, 2017, vol. 17, no. 2, pp. 93-109. DOI 10.2478/iclr-2018-0017.

\begin{abstract}
Summary: Party autonomy is a recognized concept in commercial arbitration worldwide. The traditional aspect of international arbitration where three arbitrators are appointed has been subject to criticism in the past as well as today. The appointment of a sole arbitrator purportedly allows for shorter arbitration proceedings while appointing three arbitrators tends to prolong international arbitration. The limitations of party autonomy have been moving beyond the old horizons as within current global relations the parties tend to avoid making a decision on the appointment of arbitrators themselves and thus arbitration bodies or tribunals have to act instead of them. The objective of this study is thus to provide an analysis of the issue from a broader viewpoint and to present the differences of opinion together with interesting conclusions across the expert community.
\end{abstract}

Keywords: Party autonomy, international commercial arbitration, length of arbitration proceedings, appointment of arbitrators, ad hoc arbitration, independence of arbitrators

\section{Introduction}

It is obvious that the doctrine of party autonomy has been a recognized concept in commercial arbitration worldwide. Nevertheless, the question of the extent to which freedom and party autonomy interferes with international commercial arbitration remains a frequent point of disputes and discussions.

Some studies are a source of provocative views, others are a source of inspiration. In any case, they all deserve adequate attention, such as the past and current criticism of the traditional system of the appointment of judges in international arbitration where three arbitrators are appointed. The system has been criticised due to the following reasons. ${ }^{1}$

1 This study presents a polemic against opinions expressed particularly in article ASCHAUER, Christian. Die Besetzung von Schiedsgerichten zwischen Parteiautonomie und Rechtsstaatlichkeit. Austrian Law Journal, 2016, No. 1, pp. 102-108. 
From the practical point of view, the purported critical aspect is that the appointment of a sole arbitrator allows shorter arbitration proceedings and the appointment of three arbitrators tends to prolong international arbitration.

Another important aspect of criticism is related to the appointment of arbitrators by the parties. It appears to be obvious that arbitrators are and will be dependent on the parties which appointed them.

Further, it is often mentioned that the limitations of party autonomy keep moving beyond the old horizons for in the current reality of global relations parties tend to avoid making a decision on the appointment of arbitrators and thus arbitration bodies or tribunals have to act instead.

The analysis of these issues from a broader viewpoint will present differences of opinion and interesting conclusions across the expert community.

\section{Party Autonomy in International Commercial Arbitration}

Firstly, let us recall the advantages and factors that prevail within arbitration proceedings as opposed to resolving disputes in court. For instance, it is absolutely clear that unlike judicial procedure, arbitration is faster, private and confidential and promotes a friendly atmosphere in resolving disputes. ${ }^{2}$ On the other hand, the parties must agree on the forms of arbitration, on the rules governing the arbitration proceedings, the place of arbitration, the applicable law etc. ${ }^{3}$

Further, the parties can decide on the particular arbitrators, on the location of arbitration, the language to be used in arbitration proceedings and on almost everything in the dispute settlement by arbitration. ${ }^{4}$

It is important to note that arbitration is a private procedure presided over by a private arbitrator. Finally, the decision of an arbitrator, known as an arbitration award, is a final decision having the binding effect for the parties themselves. ${ }^{5}$

With regard to the criticism mentioned above, why would the parties freely give up the positives that arise from party autonomy?

The principle of party autonomy, in the general sense, began to develop in the 19th century. Among other things, party autonomy is based on the choice of law in connection with obligations. Let us remember England and the beginnings of

2 BORALESSA, Anoosha. The Limitations of Party Autonomy in ICSID Arbitration. American Review of International Arbitration, 2004, Vol. 15, No. 2, p. 253.

3 TWEEDDAlE, Andrew, TWEEDDALE, Keren. Arbitration of Commercial Disputes. Oxford: Oxford University Press, 2007, p. 256.

4 BORALESSA, Anoosha. The Limitations of Party Autonomy in ICSID Arbitration. American Review of International Arbitration, 2004, Vol. 15, No. 2, p. 266.

5 CHUKWUMERIJE, Okezie. Choice of Law in International Commercial Arbitration. Quorum Books, 1994, p. 78. 
party autonomy in 1760, or "autonomie de volonte“" and "liberté contractuelle“ in French history. ${ }^{6}$

Within international commercial arbitration the parties can, by the means of an arbitration agreement, freely conclude on the law but also on the rules of arbitration procedure. The parties of an arbitration agreement have the right to lodge a complaint in a chosen arbitration court, but also to exclude the court jurisdiction upon agreement. The principles of party autonomy are thus far more important within international commercial arbitration than within the international contract law. ${ }^{7}$

Employing party autonomy and providing the parties with sufficient freedom to agree on the way in which the arbitration tribunal is to be set up and on the final composition of the arbitration tribunal, to lay down requirements regarding the experience, qualification or nationality of the arbitrator or arbitrators, to designate the appointing authority and to determine the number of arbitrators, is one of the most important positive consequences of party autonomy in international arbitration and as such it should not be criticised with the argument that it brings about negative risks. ${ }^{8}$

In addition, international commercial arbitration guarantees to a large extent that state courts will not interfere in arbitration. This is a crucial fact for the process. The parties must agree - and in most situations they are willing to do so - on the appointment of arbitrators. In the case that they do not come to an agreement or disagree, arbitrators can be appointed by arbitration institutions or court upon the request of the parties. ${ }^{9}$

Some authors share the idea that the success of international arbitration is considerably connected with the quality of arbitrators. ${ }^{10}$ Arbitrators make binding decisions and have wide decision-making powers to decide or resolve a dispute.

Contrary to the criticism outlined above, most authors support the idea that the basic principle of arbitration is the parties' selection of arbitrators who are involved in resolving their dispute. ${ }^{11}$ The selection of arbitrators should pro-

6 COLLINS, Lawrence (ed.). Dicey, Morris and Collins on The Conflict of Laws, vol 2. 14th ed. London: Sweet\&Maxwell, 2010, pp. 32-34.

7 CARBONNEAU, Thomas E. The Exercise of Contract Freedom in Making of Arbitration Agreements. Vanderbilt Journal of Transnational Law, 2003, Vol. 36, p. 1189.

8 ONYEMA, Emilia. Selection of Arbitrators in International Commercial Arbitration. International Arbitration Law Review, 2005, Vol. 8, No. 2, p. 46.

9 REDFERN, Alan, HUNTER, Martin. Redfern and Hunter on International Arbitration, Student Version. Oxford: Oxford University Press, 2009, p. 4.34.

10 CHATTERJEE, C. The Reality of The Party Autonomy Rule In International Arbitration. Journal of International Arbitration, 2003, Vol. 20, No. 6, pp. 539-560.

11 HOFFMANN, Leonard. Changing Perspectiveson Civil Litigation. The Modern Law Review, 1993, Vol. 56, No. 3, p. 297. 
mote confidence in the international arbitration process, and thus the investment of the parties in the choice of arbitrators has long been considered a good and established practice. ${ }^{12}$

As to the dependence or possible bias of the arbitrators in view of their appointment by the parties it is possible that there arise situations which may create doubt, for instance when the arbitration candidates are allowed a limited conversation with legal representatives of the parties, nevertheless, such conversation may be carried out only provided that there exist guarantees that a discussion on the merits of the case will be avoided. ${ }^{13}$

Nevertheless, the essential thing is that the litigants often identify the advantages of direct selection of the arbitration tribunal rather that leaving the selection of arbitrators entirely at the discretion of the arbitration institution. Also, since there exists the possibility of rejecting a proposed arbitrator, the party may feel more comfortable and know that the case will be decided by someone who is qualified, fair and maybe even clever. ${ }^{14}$

Those who are not familiar with international arbitration sometimes express their surprise about the level of participation of the parties in the selection process, and in this context they suspect the introduction of a corruption factor into the independence of arbitrators. ${ }^{15}$ Nevertheless, the rationale for a higher participation and invention of the parties becomes evident when taking account of the difference between national and international arbitration and also between ad hoc and institutional arbitration. ${ }^{16}$

It remains true that the selection of private decision-makers naturally links with choosing people from the same business and professional community as the one that relates to the parties and their representatives, which raises tension

12 REDFERN, Alan, HUNTER, Martin. Redfern and Hunter on International Arbitration, Student Version. Oxford: Oxford University Press, 2009, p. 2.176.

13 ONYEMA, Emilia. Selection of Arbitrators in International Commercial Arbitration. International Arbitration Law Review, 2005, Vol. 8, No. 2, p. 47

14 Compare ICC Arbitration Rules, Article 8.3 and 8.4, INTERNATIONAL CHAMBER OF COMMERCE. Arbitration Rules [online]. iccwbo.org, 1 March 2017 [cit. 1. 7. 2017]. Accessible at $<$ https://iccwbo.org/dispute-resolution-services/arbitration/rules-of-arbitration/>.; ICDR Rules Article 6. INTERNATIONAL CENTRE FOR DISPUTE RESOLUTION. International Dispute Resolution Procedures (Including Mediation and Arbitration Rules): English [online]. icdr.org, 1 July 2016 [cit. 1 July 2017]. Accessible at <https:// www.icdr.org/icdr/faces/i_search/i_rule/i_rule_detail?doc=ADRSTAGE2025301\&_ afrLoop $=163277989018227$ \&_afrWindowMode $=0$ \&_afrWindowId $=1 \mathrm{a} 4 \mathrm{w} 45 \mathrm{rk} 1 \mathrm{n}$ 161\#\%40\%3F_afrWindowId\%3D1a4w45rk1n_161\%26_afrLoop\%3D16327798901 8227\%26doc\%3DADRSTAGE2025301\%26_afrWindowMode\%3D0\%26_adf.ctrlstate\%3D1a4w45rk1n_221>.

15 TUFTE-KRISTENSEN, Johan. The unilateral appointment of co-arbitrators. Arbitration International, 2016, Vol. 32, No. 3, p. 484.

16 ONYEMA, Emilia. Selection of Arbitrators in International Commercial Arbitration. International Arbitration Law Review, 2005, Vol. 8, No. 2, p. 47. 
between the two principles: party autonomy during the selection of arbitrators of one's choice on the one hand, and the concept of judicial justice, independence and impartiality on the other. ${ }^{17}$

Traditional ethical models serve as a point of departure for assessing the qualification of those to whom business managers, investors, or sometimes even nations entrust their assets and welfare. However, every model must be flexible enough so as to address new professional challenges. Particularly shameful are those situations in which lawyers assume various professional roles, presenting arguments as representatives of the parties on proposals which remain open in a case and deciding as arbitrators in the same cases. In the view of these exceptional states we perceive the urgency of setting standards for the assessment of independence and impartiality of arbitrators and eventual punitive measures. ${ }^{18}$ Within the concept of the development of international arbitration the basic ethical premises, ethical values of an arbitrator and the ways to guarantee them have already been established.

The independence and impartiality of an arbitrator clearly belong among these. In this context, it is appropriate to distinguish one concept from another. Impartiality is understood in a way that the arbitrator is not in favor of any of the parties and is not biased towards the subject of the dispute. Impartiality is difficult to prove because it represents the mental attitude of the arbitrator towards the parties to the dispute. Independence, on the other hand, requires that the arbitrator be in any relation to the parties to the dispute that could influence the arbitrator's decision. As regards to proving the absence of the arbitrator's independence, there must be an objective existence of a relationship between the arbitrator and the party. ${ }^{19}$

Most rules of procedure of arbitration institutions include provisions on the arbitrator's duty to disclose any information that he or she believes might have an effect on independence and impartiality towards the parties in the dispute. The arbitrator must disclose such information no later than at his or her appointment. If they occur after the arbitrator's appointment, his or her duty is still valid. This institute, which serves primarily to maintain a good standard of independence and impartiality of an arbitrator, can be found in the model law

17 Compare the Decision Laker Airways Inc. v FLS Aerospace Ltd [2000], Decision of the Court of Appeal, Smith v Kvaerner cementation Foundations Ltd [2006] EWCA Civ 242, Section 17.

18 NEIL, Andrews. Global Perspectives on Commercial Arbitration. In GOTTWALD, Peter, HESS, Burkhard (eds.). Procedural Justice XIV, IAPL World Congress Heidelberg, 2011. Bielfeld: Gieseking- Verlag, 2014, p. 594.

19 LEW, Julian, MISTELIS, Loukas, KROLL, Stefan. Comparative International Commercial Arbitration. Kluwer Law International, 2003, pp. 260-270. The same opinion expressed by Gary Born: BORN, G. International Commercial Arbitration Vol. I. Aalphen aan den Rijn: Kluwer Law International, 2009, p.1473. 
UNCITRAL, more precisely in Article 12 (1). This model law has inspired many arbitration institutions. ${ }^{20}$

In connection with this issue, we must not forget the 2004 IBA Guidelines on Conflict of Interests in International Arbitration (further referred to as IBA Guidelines). IBA Guidelines become binding only after their incorporation into the arbitration agreement, nevertheless, within the context of international arbitration they have become well known. They contain a general clause where the general requirement for the arbitrator's neutrality has been formulated. The peculiarity of this universal document is in that it contains a demonstrative list of reasons that cast doubt on the impartiality and neutrality of the arbitrator. The list is divided into four categories according to the seriousness of the reasons. ${ }^{21}$

One of the extraordinary benefits of arbitration is its privateness. The implications of the privateness of arbitration include the principle connected with ethics - the confidentiality of an arbitrator. Confidentiality, coupled with privateness of the proceedings, creates a balanced composition that aims to provide the parties to the dispute with the convenience of a fair procedure free of media exposure, as well as to prevent the abuse of sensitive information related to the proceedings. $^{22}$

Some degree of secrecy depends on the jurisdiction and on the terms that the parties agree on. As to the arbitrator's discreetness, we may observe two approaches. The first approach involves privateness of oral hearings and of the arbitration award. This approach is referred to as privacy. The second approach, referred to as confidentiality, involves an absolute duty to remain silent about anything that relates to the dispute and anything stated during the proceedings. ${ }^{23}$

The arbitrator is also supposed to conduct the proceedings with professional care. Although most international law related to arbitration does not place any special demands on the qualification of an arbitrator, the arbitrator must be able to ensure the smooth running of the proceedings, to perform procedural acts and to make the arbitration award. Failure to perform his or her duties during the arbitration may establish grounds for the arbitrator's removal.

The arbitrator should set a good example for society. This is demonstrated in the provisions of Article 4 of the Bangalore Principles stating that: "dignified representation in the exercise of the office as well as in private life is a matter of course

20 MOSES, M. L. The Principles and practice of international commercial arbitration. 1st ed. Cambridge: Cambridge University Press, 2008, pp. 130-132.

21 BORN, G. International Commercial Arbitration Vol. I. Aalphen aan den Rijn: Kluwer Law International, 2009, p. 1517

22 LISSE, Luděk. Mlčenlivost rozhodce (Confidentiality of an Arbitrator) [online]. Elaw.cz, 18 February 2011. Accessible at <http://www.elaw.cz/cs/ostatni/382-mlcenlivost-rozhodce. html $>$.

23 TWEEDDALE A., TWEEDDALE, K. Arbitration of commercial disputes : International and English law practice 1st ed. Oxford: Oxford University Press, 2007, p. 350. 
for every judge. ${ }^{24}$ An arbitrator, as well as a judge, is one of the most respected professions and hence should set a good example to others.

\section{Limitations of Party Autonomy}

Certainly, party autonomy is not unquestioned and it is linked to certain limitations connected with equal treatment, third person, arbitration agreement, arbitrability, institutional arbitration and its rules, and public order.

\subsection{The Principle of Equality of the Parties}

The parties are sufficiently autonomous to agree on their own arbitration procedure, nevertheless, it cannot be implemented so as to violate provisions related to equal treatment of the parties themselves. Sometimes the rules chosen by the parties can be interpreted in a way leading to unfair treatment. Then it becomes the duty of arbitrators and even national courts to preserve the basic attributes of arbitration proceedings and to restrict party autonomy. Nevertheless, such limitations have been widely accepted by the experts. ${ }^{25}$

\subsection{Third Person}

The arbitration agreement applies only to parties which are a part of it, thus parties cannot agree on something that would have a negative impact on a third person.

Even the arbitration court usually has little power to require a third person to appear as a witness or to file documents or deposit any amount etc. Although there already exists a standard exemption from this limitation for the arbitration tribunal. The arbitration tribunal can obtain this right by the approval and on the basis of legal assistance from the part of national courts. ${ }^{26}$

24 The Bangalore Principles of Judicial Conduct, from 25-26 November 2002, Section 4

25 UNCITRAL. UNCITRAL Model Law on International Commercial Arbitration 1985 [online]. uncitral.org, 1985 [cit. 1 July 2017]. Accessible at <http://www.uncitral.org/pdf/ english/texts/arbitration/ml-arb/06-54671_Ebook.pdf $>$., Article 28, UNCITRAL. UNCITRAL Model Law on International Commercial Arbitration 1985 with amendments as adopted in 2006 [online]. uncitral.org, 2008 [cit. 1 July 2017]. Accessible at < http://www. uncitral.org/pdf/english/texts/arbitration/ml-arb/07-86998_Ebook.pdf $>$., Article 35, The New York Convention on the Recognition and Enforcement of Foreign Arbitral Awards concluded on June 10, 1958 in New York; order of the Ministry of Foreign Affairs No. 74/1959 Coll., Article V 1d and the UNCITRAL Rules recognizing it as binding provisions that should not be departed from.

26 MUSTILL, Michael John. Comments and Conclusions. In Conservatory Provisional Measures in international Arbitration, 9. Joint Colloquim. ICC Publication, 1993, p. 118. To preliminary measures: HRNČIŘÍKOVÁ, Miluše, VALENTOVÁ, Lucia. Judiciální trendy $v$ mimosoudním řešeni preshraničnich sporů. (Judicial Trends in the Out-of-court Settlement of Cross-border Disputes.) 1st edition. Praha: Leges, 2016, p. 29. 


\subsection{Arbitration Agreement}

By the arbitration agreement the parties undertake to refer their dispute to an arbitrator or to a court of arbitration which will resolve it in an alternative manner. With regard to party autonomy the agreement shall be distinguished from other agreements concluded in the course of arbitration proceedings, namely the agreement with the arbitrator and the agreement on the arbitration proceedings.

The major characteristic of the agreement with the arbitrator is that, unlike the arbitration agreement binding the parties, this agreement focuses more on the relationship between the parties and the arbitrator. The agreement on the arbitration proceedings regulates the agreement on the course of arbitration proceedings, composition of the tribunal etc., i.e. the arbitration procedure. This type of agreement may appear in the arbitration agreement itself and on its basis the parties can agree in advance on further matters relating to the course of the proceedings such as arbitrator's fees, costs of proceedings etc.

The agreement, being the product of party autonomy, acts as a limitation too. Anything, that the parties agreed upon in the agreement, is binding on them and later the parties must not deviate from the provisions of the agreement without meeting further requirements. ${ }^{27}$

\subsection{Arbitrability}

Arbitrability relates to whether it is or it is not appropriate to resolve an issue by the means of the arbitration proceedings, or whether it is possible to resolve it through arbitration. However, this is not purely a legal issue and therefore it is certainly also a question of party autonomy.

The term arbitrability refers to the fitness of a particular dispute between parties to be the subject of arbitration proceedings. ${ }^{28}$ A number of authors distinguish between objective arbitrability, a set of relationships defined by positive law in which it is generally possible to appoint an arbitrator of the parties choice and entrust him or her with finding the law, and subjective arbitrability i.e. specific relationships which the parties have chosen to arbitrate upon in the arbitration agreement. ${ }^{29}$ In the light of the New York Convention, Domenico di Pietro states that arbitrability ratione materiae is a concept that normally refers

27 CHUKWUMERIJE, Okezie. Choice of Law in International Commercial Arbitration. Quorum Books, 1994, p. 30.

28 THOMSON REUTERS PRACTICAL LAW. DAC Report on Arbitration Bill 1996 [online]. uk.practicallaw.thomsonreuters.com, 1996. Accessible at <https://uk.practicallaw.thomsonreuters.com/w-004-4914?transitionType $=$ Default\&contextData $=($ sc.Default $) \&$ firstPag e=true\&bhcp=1>., Section 100 et seq. The 1996 DAC Report on the English Arbitration Bill: The Last Part. Arbitration International, 1999, Vol. 15, No. 4, pp. 413-433.

29 RABAN, Přemysl. Alternativní řešení sporů, arbitráž a rozhodci v České a Slovenské republice a zahraničí. (Alternative Dispute Settlement, Arbitration and Arbitrators in the Czech and Slovak Republic and Abroad.) Praha: C. H. Beck, 2004, p. 75. 
to objective arbitrability, independent of the capabilities and will of the parties. He then distinguishes it from so-called ratione personae, or subjective arbitrability, which relates to the capability and will of the parties to bring their disputes before independent arbitrators. ${ }^{30}$

The lack of arbitrability, sometimes in conjunction with a subjective and an objective view of this issue may be one of the reasons for the annulment of an arbitration award on the basis of lex-arbitri. ${ }^{31}$

\subsection{Institutional Arbitration}

This is another, but unlike the previous ones, a rather positive limitation to party autonomy. If parties prefer institutional arbitration to ad hoc arbitration, the freedom to create procedural rules will be subject to predetermined norms of the chosen institution. It would be difficult and rather unlikely that the institution would agree on rules applied by any other arbitration institution. ${ }^{32}$ In addition to this aspect, arbitration institutions pay attention to ethics in commercial arbitration themselves.

\subsection{Commercial Arbitration Codes of Ethics}

First, we can mention the AAA/ABA Code of Ethics for Arbitrators in Commercial Disputes. It is a code of ethics from 1977 which was prepared in conjunction with the American Arbitration Association and American Bar Association. ${ }^{33}$ Similar codes of ethics were adopted by the Milan Chamber of National and International Arbitration ${ }^{34}$, the Singapore International Arbitration Centre and the Cairo Regional Centre for International Commercial Arbitration ${ }^{35}$.

30 MISTELIS, Loukas A. Arbitrability - International and Comparative Perspectives. Is Arbitrability a National or an International Law Issue? In MISTELIS, Loukas A., BREKOULAKIS, Stavros L. Arbitrability: International \& Comparative Perspectives. Kluwer Law International, 2008, p. 6; In more detail: DI PIETRO, Domenico. General Remarks on Arbitrability Under the New York Convention. In MISTELIS, Loukas A., BREKOULAKIS, Stavros L. Arbitrability..., pp. 85-87.

31 PARK, William. Arbitrators and Accuracy. Journal of International Dispute Settlement, 2010, Vol. 1, No. 1, p. 27.

32 THOMSON REUTERS PRACTICAL LAW. DAC Report on Arbitration Bill 1996 [online]. uk.practicallaw.thomsonreuters.com, 1996 [cit. 1 July 2017]. Accessible at <https:// uk.practicallaw.thomsonreuters.com/w-004-4914?transitionType=Default\&contextData $=$ (sc.Default)\&firstPage=true\&bhcp=1>., Section 100 et seq., The 1996 DAC Report on the English Arbitration Bill: The Last Part. Arbitration International, 1999, Vol. 15, No. 4, p. 413-433.

33 The Code of Ethics for Arbitrators in Commercial Disputes (March 1, 2004). Accessible at: $h t t p: / / w w w . a d r . o r g / s i . a s p ? i d=1620$.

34 Milan Chamber of Commerce, International Arbitration Rules: Code of Ethics ofArbitrators. Accessible at: http://www.jus.uio.no/lm/milan.chamber.of.commerce.international. arbitration.rules.2004/a1 (last visited December 1, 2007)

35 Cairo Regional Centre for International Commercial Arbitration, Code of Ethics. Accessible at: http://www.crcica.org.eg/code_ethics.html (last visited November 18, 2007). 
Similarly, the International Bar Association Guidelines on Conflict of Interest in International Arbitration have been created. Nevertheless, ethical standards are not binding rules. They are only rules or principles of conduct that the arbitrators should follow. They are not binding until the parties incorporate them into the agreement themselves and demonstrate the will to be bound by them. ${ }^{36}$

If an institution is lacking a code of ethics, we usually find rules of conduct in the Rules of Arbitration. Let us see for instance Article 7 of the ICC Rules of Arbitration which provides for the most important ethical values - independence and impartiality. The specific provisions of this article read: "an arbitrator must remain independent and impartial in relation to the parties in the dispute throughout the arbitration proceedings."

The ethical principles of international arbitration are linked to party autonomy and are regulated in the Arbitration Code of Ethics. The code is divided into 10 "Canons", of which only four are relevant for the assessment of this issue. Canon III. ${ }^{37}$ regulates the means of communication between an arbitrator and the parties, stating, inter alia, that an arbitrator should not conduct negotiations without the presence of one of the parties, with the exception of situations stated in the code.

The recommendation also concerns the written communication between the arbitrator and the parties. In the course of a written communication with one party the arbitrator should always acknowledge the other party of the content of the communication by sending a copy of the given notification. The same applies to notifications related to the given case which the arbitrator obtains from one of the parties. In connection with the latter, it is possible to depart from the agreement or, as the case may be, the rules of arbitration can determine otherwise.

Under Canon IV of the Code of Ethics ${ }^{38}$ the arbitrator shall conduct the proceedings against all parties fairly and allow them to provide all relevant evidence for the case. This evidence shall be produced in the presence of all other parties, except for the cases in which one of the parties does not arrive, provided that the party has been familiar with the conduct of the proceedings and failed to appear without giving any excuse.

The most important principle is the arbitrator's impartiality. Canon $\mathrm{V}^{39}$ regulates that the outcome of arbitration proceedings is an arbitration award which should be made by the arbitrator following a thorough consideration and assessment of all facts obtained during the proceedings, taking into account the princi-

36 IBA Guidelines on Conflicts of Interest in International Arbitration (May 22, 2004). Accessible at: $h t t p: / / w w w$.ibanet.org/images/downloads/guidelines\% 20text.pdf.

37 Original version: An arbitrator should avoid impropriety or the Appearance of impropriety in communicating with parties.

38 Original version: An arbitrator should conduct the proceedings fairly and diligently.

39 Original version: An arbitrator should make decisions in a just, independent and deliberate manner. 
ple of impartiality. The arbitrator should not be influenced by external influences that might create bias and establish reasonable doubts about his or her impartial decision.

The last ethical principle relevant for this issue is regulated in Canon VI and deals with confidentiality, or secrecy. Arbitration is grounded in the parties trust in a third, objective and impartial, person, i.e. the arbitrator. The arbitrator is bound by secrecy regarding all facts and information obtained in the course of the arbitration proceedings held in the presence of all parties.

In this context it is worth highlighting the fact that mediation is based on the same principles, except for that the mediator is allowed, and even recommended, to listen to individual parties during separate meetings without the participation of the other party. This is a demonstration of the principle of self-determination of the parties, nevertheless, the principle of confidentiality must be respected. This is where there is a perceived conflict of individual types of proceedings, since private communication between the arbitrator and individual parties is, save for a few exceptions, forbidden in arbitration proceedings.

Further sources of professional ethics can be found in international conventions. The absence of the national regulation of professional ethics for arbitrators is thus not regarded as a disadvantage. We may infer that "the status of international arbitrators is too important and delicate to cover the problem fully by national legislation ${ }^{40}$. As a result, the issues related to the status of an arbitrator are not addressed on the national level and therefore it would not be appropriate to address issues related to professional ethics of an arbitrator on a national level in connection with international arbitration. This deficiency is fully compensated by case-law and professional literature. ${ }^{41}$

\subsection{Public order}

The last, yet not the least important and at the same time the most common limitation, is public order. This limitation is due to the existence of the concept of state sovereignty, so that every state can define the boundaries within which arbitration can take place.

Public order is not a subject of any precise definition. Nevertheless, it can be said that it refers to the minimum rules that the parties must follow. This concept depends on cultural, social and economic tradition of each country. ${ }^{42}$

40 BORN, G. International Commercial Arbitration Vol. I. Aalphen aan den Rijn : Kluwer Law International, 2009, p. 1593.

41 Ibid.

42 BRUCE, Fiona. Case Comment: Ust-Kamenogorsk Hydropower Plant JSC v AES Ust-Kamenogorsk Hydropower Plant LLP [2013] UKSC 35 [online]. ukscblog.com, 30 July 2013 [cit. 1 July 2017]. Accessible at $<$ http://ukscblog.com/case-comment-ust-kamenogorsk-hydropower-plant-jsc-v-aes-ust-kamenogorsk-hydropower-plant-llp-2013-uksc-35>. 
This can be supported by well-known case-law. In the decision referred to as Mastrobuon v. Shearson Lehman Hutton Inc. the Supreme Court of the United States stated that "Parties have a general freedom to structure their arbitration agreement the way they see it appropriate... though with some limitations. ${ }^{{ }^{4} 43}$

In Peh Teck Quee at the Bayerische Landesbank Girozentrale, the Singapore Court of Appeal found that "the parties may use their autonomy to draw up an agreement, but if the execution of such an agreement is in conflict with public order, the agreement will be declared void on this point. ${ }^{44}$

\section{Appointment of the Arbitration Tribunal as One of the Advantages of Arbitration}

In the case that a dispute is resolved by a court the parties do not have the option to choose their judge. The choice of an arbitrator is not considered a positive and is neither accepted or applied by the parties only in exceptional situations, including for example those in which the subjects of international commercial arbitration are international companies with enormous budgets and global interests. Disputes between multinational companies have certain specificities. Such disputes should be resolved by people with relevant expertise. Arbitration and the principle of party autonomy enable the parties to choose persons with relevant expert knowledge and experience as arbitrators. Or, if they do not have time or lack willingness to act, they may let the court of arbitration or an arbitration body decide for them. ${ }^{45}$

Arbitration bodies shall generally appoint arbitrators in the case that the parties fail to agree on arbitrators. The arbitrators shall have some qualifications. Additionally, arbitrators shall have a good knowledge of the language of the arbitration proceedings. Arbitrators shall have appropriate expertise, education and experience. Besides these qualifications, arbitrators shall be independent and impartial during arbitration. Independence is based on the fact that arbitrators do not have any significant social, economic and personal relations with the parties in the dispute. As far as impartiality is concerned, arbitrators shall not be biased towards the parties. ${ }^{46}$

The last aspect to be mentioned in this section is the objection to the person of the arbitrator. In the case that arbitrators are not independent and impar-

43 Decision of the US Supreme Court from 6 March 1995, Mastrobuono v. Shearson Lehman Hutton, Inc., 514 U.S. 52 (1995).

44 Decision of the Court of Appeal from 3 November 1999, Peh Teck Quee v Bayerische Landesbank Girozentrale, [2000] 1 SLR 148; [1999] SGCA 79.

45 REDFERN, Alan, HUNTER, Martin. Redfern and Hunter on International Arbitration, Student Version. Oxford: Oxford University Press, 2009, to the issue: 4.41 and 7.11.

46 WERNER, Jacques. Intellectual Property Disputes and Arbitration - A Comment on a Recent ICC Report. The Journal of World Intellectual Property, 1998, Vol. 1, No. 5, p. $841-860$. 
tial during the arbitration proceedings, they may be challenged by the parties. In this respect, the possibility to challenge the person of the arbitrator and his or her course of action may be seen as a guarantee of party autonomy because a dependent and biased arbitrator will not meet the expectations and wishes of the parties and thus will not respect the party autonomy. ${ }^{47}$ According to the UNCITRAL Arbitration Rules an arbitrator may be challenged if circumstances exist that give rise to justifiable doubts as to his impartiality or independence. ${ }^{48}$

With regard to English law, under the English Arbitration Act $^{49}$ parties to arbitration proceedings may apply to the court to remove an arbitrator if circumstances exist that give rise to justifiable doubts as to his impartiality or if he does not possess the qualifications required by the arbitration agreement, if he is incapable of conducting the proceedings or he has refused or failed properly to conduct the proceedings, or failed to use all reasonable despatch in conducting the proceedings or making an award all the while following the rules of arbitration institutions or the lex loci of the Arbitration Act.

\section{Conclusion}

As far as the criticism regarding the appointment of three arbitrators is concerned, from the practical point of view, the critical aspect relates to the fact that the appointment of a sole arbitrator purportedly shortens the arbitration process and the appointment of three arbitrators tends to prolong international arbitration. The question ensuing from the presented critical thoughts reflects the speed of international arbitration. ${ }^{50}$

However, a more important aspect is that this practical and critical area of opinion is to be linked to ad hoc arbitration and does not fall under the issues related to institutional arbitration. In my opinion, arbitration in an arbitration tribunal may be speedier than arbitration conducted through a sole arbitrator.

Another important aspect of criticism of party autonomy which concerns the appointment of arbitrators by the parties is that it should be a matter-of-course that the arbitrators are dependent on the parties who appointed them. We can say that it is so, however just partially, only in the context of acceptable tension

47 DONAHEY, M. Scott. The Independence and Neutrality of Arbitrators. Journal of International Arbitration, 1992, Vol. 9, No. 4, p. 31

48 UNCITRAL. UNCITRAL Arbitration Rules [online]. uncitral.org, 2017 [cit. 1 July 2017]. Accessible at <http://www.uncitral.org/pdf/english/texts/arbitration/arb-rules-2013/ UNCITRAL-Arbitration-Rules-2013-e.pdf>., Article. 12.; UNCITRAL. UNCITRAL Model Law on International Commercial Arbitration 1985 with amendments as adopted in 2006 [online]. uncitral.org, 2008 [cit. 1 July 2017]. Accessible at <http://www.uncitral.org/pdf/ english/texts/arbitration/ml-arb/07-86998_Ebook.pdf >., Articles 12 and 13 et seq.

49 Article 24 of the English Arbitration Act.

50 SOBICH, Phillip. Die Civil Procedure Rules 1999 - Zivilprozessrecht in England. Juristen Zeitung, 1999, p. 775. 
between two principles of international commercial arbitration - independence of the party in the selection of arbitrators at its own discretion on the one hand and compliance with the principle of justice, independence and impartiality of arbitrators on the other. ${ }^{51}$

Although theoretically it is possible and sometimes it happens that the arbitrator is willing to pronounce verbal structures in the sense of "I have lost my case again" and it is true that we do not expect such conclusions from an arbitrator but rather from the representative of the party, situations in which arbitrators appointed by the parties are truly independent appear to be a matter of exception. One cannot imagine a professional arbitrator being captivated by pursuing the interests of the party who appointed him or her. It is more common that arbitrators appointed by the parties monitor or control the procedure of the chairman of the arbitration tribunal.

Moreover, although proven particularly by psychological studies focusing on the behaviour of arbitrators, it turns out that notwithstanding the fact that arbitrators sometimes identify with the party that has appointed them, the relations within the equilibrium of the arbitration tribunal are maintained and they are a sufficient guarantee of an independent award. ${ }^{52}$

Furthermore, as to the opinion that these critical aspects lead to a situation where the limitations of party autonomy are shifted beyond the old horizons and the parties are not willing to decide on the appointment of arbitrators, the decision thus being left to arbitration institutions, it is obvious that, on the contrary, parties involved in international arbitrations purposefully and deliberately use the services of institutional arbitration courts and do not waste time searching for arbitrators, which, in turn, corresponds to the speedy arbitration proceedings, and not to the will of losing benefits connected with party autonomy. Making use of such support offered to parties of international arbitration is undoubtedly a significant manifestation of party autonomy within institutionalized arbitration proceedings. ${ }^{53}$

Further discussion could cover situations in which the parties are divided over a particular arbitrator, and, in the case that they fail to reach an agreement, whether a single arbitrator or a tribunal will decide. ${ }^{54}$ It may seem that the par-

51 To impartiality and independence compare the opinion of Lord Bingham of Cornhill, HOUSE OF LORDS. Judgments - Magill v. Porter Magill v. Weeks [online]. publications. parliament.uk, 13 December 2001 [cit. 1 July 2017]. Accessible at <https://publications. parliament.uk/pa/ld200102/ldjudgmt/jd011213/magill-1.htm >. Decision of the Court of Appeal from 13 December 2001, Magill v. Porter v. Weeks, [2001] UKLH 67.

52 BIGHAM, Tom. The Business of Judging. Oxford: Oxford University Press, 2000, p. 59.

53 Compare with REDFERN, Alan, HUNTER, Martin. Redfern and Hunter on International Arbitration, Student Version. Oxford: Oxford University Press, 2009, p. 4.30.

54 Compare with the Rules of VIENNA INTERNATIONAL ARBITRAL CENTRE. Wiener Regeln [online]. viac.eu, 1 July 2013 [cit. 1 July 2017]. Accessible at $<$ http://www.viac.eu/ de/schiedsverfahren/wiener-regeln $>$, Schiedsordnung, Wiener Regeln, 2013, wording 
ties do not have "their" arbitrator, nevertheless, in my opinion, this is not a situation where party autonomy is limited, but a positive aspect linked to the possibility of using arbitration rules in the case that the parties fail to reach a consensus.

In conclusion, let us thank all the authors for the courageous expressions of their subjective insights and inspiration for dissenting opinions on some aspects mentioned by them and also for the initiation of the intent to write this short study.

\section{References}

ASCHAUER, Christian. Die Besetzung von Schiedsgerichten zwischen Parteiautonomie und Rechtsstaatlichkeit. Austrian Law Journal, 2016, No. 1, pp. 102-108.

BIGHAM, Tom. The Business of Judging. Oxford: Oxford University Press, 2000. 434 p.

BORALESSA, Anoosha. The Limitations of Party Autonomy in ICSID Arbitration. American Review of International Arbitration, 2004, Vol. 15, No. 2, 58 p.

BRUCE, Fiona. Case Comment: Ust-Kamenogorsk Hydropower Plant JSC v AES UstKamenogorsk Hydropower Plant LLP [2013] UKSC 35 [online]. ukscblog.com, 30 July 2013 [cit. 1 July 2017]. Accessible at <http://ukscblog.com/case-comment-ustkamenogorsk-hydropower-plant-jsc-v-aes-ust-kamenogorsk-hydropower-plant-llp2013-uksc-35>.

CARBONNEAU, Thomas E. The Exercise of Contract Freedom in Making of Arbitration Agreements. Vanderbilt Journal of Transnational Law, 2003, Vol. 36, pp. 1189-1232.

COLLINS, Lawrence (ed.). Dicey, Morris and Collins on The Conflict of Laws, vol 2. 14th edition. London: Sweet\&Maxwell, 2010. 1950 p.

DONAHEY, M. Scott. The Independence and Neutrality of Arbitrators. Journal of International Arbitration, 1992, Vol. 9, No. 4, pp. 31-42.

English Arbitration Act.

GOTTWALD, Peter, HESS, Burkhard (eds.). Procedural Justice XIV, IAPL World Congress Heidelberg, 2011. Bielfeld: Gieseking-Verlag, 2014. 721 p.

HOFFMANN, Leonard. Changing Perspectives on Civil Litigation. The Modern Law Review, 1993, Vol. 56, No. 3, pp. 297-306.

HOUSE OF LORDS. Judgments - Magill v. Porter Magill v. Weeks [online]. publications. parliament.uk, 13 December 2001 [cit. 1 July 2017]. Accessible at https://publications. parliament.uk/pa/ld200102/ldjudgmt/jd011213/magill-1.htm>.

HRNČIŘÍKOVÁ, Miluše, VALENTOVÁ, Lucia. Judiciální trendy v mimosoudním řešení přshraničních sporů. (Judicial Trends in the Out-of-Court Settlements of Cross-border Disputes.) 1st edition. Prague: Leges, 2016. 176 p.

CHATTERJEE, C. The Reality of The Party Autonomy Rule In International Arbitration. Journal of International Arbitration, 2003, Vol. 20, No. 6, pp. 539 - 560.

CHUKWUMERIJE, Okezie. Choice of Law in International Commercial Arbitration. Quorum Books, 1994. 218 p.

according to Article 17 of the Rules. 
INTERNATIONAL CENTRE FOR DISPUTE RESOLUTION. International Dispute Resolution Procedures (Including Mediation and Arbitration Rules): English [online]. icdr.org, 1 July 2016 [cit. 1 July 2017]. Accessible at <https://www. icdr.org/icdr/faces/i_search/i_rule/i_rule_detail?doc=ADRSTAGE2025301\&_ afrLoop $=163277989018227$ \&_afrWindowMode=0\&_afrWindowId=1a4w45rk1n 161\#\%40\%3F_afrWindowId\%3D1a4w45rk1n_161\%26_afrLoop\%3D16327798901 8227\%26doc\%3DADRSTAGE2025301\%26_afrWindowMode\%3D0\%26_adf.ctrlstate\%3D1a4w45rk1n_221>.

INTERNATIONAL CHAMBER OF COMMERCE. Arbitration Rules [online]. iccwbo. org, 1 March 2017 [cit. 1 July 2017]. Accessible at <https://iccwbo.org/dispute-resolution-services/arbitration/rules-of-arbitration/>.

MUSTILL, Michael John. Comments and Conclusions. In Conservatory Provisional Measures in international Arbitration, 9. Joint Colloquim. ICC Publication, 1993, p. 118.

ONYEMA, Emilia. Selection of Arbitrators in International Commercial Arbitration. International Arbitration Law Review, 2005, Vol. 8, No. 2, pp. 45-54.

PARK, William. Arbitrators and Accuracy. Journal of International Dispute Settlement, 2010, Vol. 1, No. 1, pp. 25-53.

REDFERN, Alan, HUNTER, Martin. Redfern and Hunter on International Arbitration, Student Version. Oxford: Oxford University Press, 2009. 727 p.

Judgment of the Court of Appeal from 13 December 2001, Magill v. Porter v. Weeks, [2001] UKLH 67.

Judgment of the Court of Appeal from 3 November 1999, Peh Teck Quee v Bayerische Landesbank Girozentrale, [2000] 1 SLR 148; [1999] SGCA 79.

Judgment of the Court of Appeal, Smith v Kvaerner Cementation Foundations Ltd, 2006, EWCA civ. 242.

Decision Laker Airways Inc. V. FLS Aerospace Ltd, 2000.

Judgment of the US Supreme Court from 6 March 1995, Mastrobuono v. Shearson Lehman Hutton, Inc., 514 U.S. 52 (1995).

SOBICH, Phillip. Die Civil Procedure Rules 1999 - Zivilprozessrecht in England. Juristen Zeitung, 1999, pp. 775 - 780.

The 1996 DAC Report on the English Arbitration Bill: The Last Part. Arbitration International, 1999, Vol. 15, No. 4, pp. 413-433.

THOMSON REUTERS PRACTICAL LAW. DAC Report on Arbitration Bill 1996 [online]. uk.practicallaw.thomsonreuters.com, 1996 [cit. 1 July 2017]. Accessible at <https:// uk.practicallaw.thomsonreuters.com/w-004-4914?transitionType=Default\&context Data $=($ sc. Default $) \&$ firstPage $=$ true $\& b h c p=1>$.

TUFTE-KRISTENSEN, Johan. The Unilateral Appointment of Co-arbitrators. Arbitration International, 2016, Vol. 32, No. 3, pp. 483-503.

TWEEDDALE, Andrew, TWEEDDALE, Keren. Arbitration of Commercial Disputes. Oxford: Oxford University Press, 2007. 1010 p.

The New York Convention on the Recognition and Enforcement of Foreign Arbitration Awards concluded on June 10, 1958; order of the Ministry of Foreign Affairs No. 74/1959 Coll., the New York Arbitration Convention. 
UNCITRAL. UNCITRAL Arbitration Rules [online]. uncitral.org, 2017 [cit. 1 July 2017]. Accessible at <http://www.uncitral.org/pdf/english/texts/arbitration/arb-rules-2013/ UNCITRAL-Arbitration-Rules-2013-e.pdf>.

UNCITRAL. UNCITRAL Model Law on International Commercial Arbitration 1985 [online]. uncitral.org, 1985 [cit. 1 July 2017]. Accessible at <http://www.uncitral.org/ pdf/english/texts/arbitration/ml-arb/06-54671_Ebook.pdf $>$.

UNCITRAL. UNCITRAL Model Law on International Commercial Arbitration 1985 with amendments as adopted in 2006 [online]. uncitral.org, 2008 [cit. 1 July 2017]. Accessible at < http://www.uncitral.org/pdf/english/texts/arbitration/ml-arb/07-86998_ Ebook.pdf>.

VIENNA INTERNATIONAL ARBITRATION CENTRE. Wiener Regeln [online]. viac. eu, 1 June 2013 [cit. 1 July 2017]. Accessible at <http://www.viac.eu/de/schiedsverfahren/wiener-regeln>.

WERNER, Jacques. Intellectual Property Disputes and Arbitration - A Comment on a Recent ICC Report. The Journal of World Intellectual Property, 1998, Vol. 1, No. 5, pp. 841-886. 